\title{
KEKERASAN TERHADAP PEREMPUAN DAN PERCERAIAN DALAM PERSPEKTIF PEMBERDAYAAN PEREMPUAN
}

\author{
Theresia Mutiara Galistya \\ Badan Pusat Statistik Kabupaten Jembrana, \\ e-mail: theresia.mutiara@bps.go.id
}

\begin{abstract}
Abstrak
Capaian pemberdayaan perempuan Indonesia melalui nilai Indeks Pemberdayaan Gender (IDG) menunjukkan peningkatan dalam satu windu terakhir. Namun di sisi lain, kecenderungan peningkatan juga terlihat pada jumlah persentase kekerasan terhadap perempuan. Idealnya, peningkatan IDG diikuti dengan penurunan jumlah kekerasan. Untuk mengetahui gambaran kondisi pemberdayaan perempuan, kekerasan terhadap perempuan, dan perceraian sebagai dampak dari kekerasan, dilakukan kajian terhadap data hasil Survei Demografi dan Kesehatan Indonesia (SDKI) tahun 2017 dan Catatan Tahunan Komisi Nasional Perempuan tahun 2018 dengan menggunakan metode analisis deskriptif dan analisis komparatif. Hasil penelitian menunjukkan bahwa indikator pemberdayaan perempuan, yakni partisipasi perempuan dalam pengambilan keputusan rumah tangga dan kontrol perempuan terhadap pendapatan yang dihasilkan oleh perempuan memiliki keterkaitan dengan ketidaksetujuan perempuan terhadap semua alasan yang membenarkan pemukulan suami terhadap istri. Secara umum, semakin tinggi partisipasi dan kontrol yang dimiliki perempuan, maka perempuan semakin tidak setuju dengan semua alasan untuk membenarkan pemukulan suami terhadap istri. Hal ini menunjukkan bahwa ke depan sikap tersebut mampu mengurangi kekerasan dalam rumah tangga (KDRT) sebagai penyebab perceraian. Meski demikian, penelitian ini masih memerlukan analisis yang lebih komprehensif. Kajian ini juga merekomendasikan perlunya upaya-upaya penguatan berbasis gender guna peningkatan pemberdayaan perempuan dalam upaya peningkatan kesejahteraan perempuan dan ketahanan keluarga.
\end{abstract}

Kata Kunci: Gender, IDG, KDRT, SDKI 2017, Ketahanan Keluarga

\begin{abstract}
The achievement of Indonesian's women empowerment through Gender Empowerment Measure (GEM) shows an increase in the last eight years. On the other hand, the increasing trend is also seen in the percentage of violence against women. Ideally the increase in GDI is followed by a decrease in acts of violence. A study of the 2017 Indonesian Demographic and Health Survey's data and also on the Annual Note of The Women's National Commission in 2018 is conduct to illustrate the conditions of women's empowerment, violence against women, and divorce as a result of violence. This study used a qualitative approach with descriptive and comparative analysis. The results indicate that the two indicators of women's empowerment, that is women's participation in household decision making and women's control of her income were related to disagreement towards domestic violence. In general, the higher of the participation and control that women have, the more women disagree with all reasons to justify beating husbands to wives. This shows that in the future this attitude can reduce domestic violence as a cause of divorce. However, this study needs more comprehensive analysis. This study also recommends the need for strengthening genderbased legislation to eliminate violence against women and will have an impact on women welfare and family resilience.
\end{abstract}

Keywords: Gender, GEM, Domestic Violence, 2017 IDHS, Family Resiliences 


\section{PENDAHULUAN}

Mencapai kesetaraan gender dan memberdayakan semua perempuan dan anak perempuan merupakan target kelima dalam Tujuan Pembangunan Berkelanjutan (Sustainable

Development

Goals/SDGs)(BPS, 2017). Selain merupakan hak fundamental manusia, kesetaraan gender juga menjadi dasar bagi terciptanya dunia yang damai, sejahtera, dan berkelanjutan (Komnas HAM, 2013). Dengan memberikan akses yang sama dengan laki-laki di bidang pendidikan, perawatan kesehatan, pekerjaan yang layak, keterwakilan dalam politik, dan pembuatan keputusan ekonomi, akan mampu mendorong ekonomi berkelanjutan, serta memberikan manfaat bagi masyarakat pada khususnya dan kemanusiaan pada umumnya (UN, 2015).

Indikator kesetaraan dan pemberdayaan gender di Indonesia salah satunya ditunjukkan dengan Indeks Pemberdayaan Gender (IDG). Dari IDG dapat dilihat partisipasi perempuan dalam kehidupan ekonomi, partisipasi politik, dan pengambilan keputusan. Capaian IDG di Indonesia pada kurun waktu tahun 20102017 terus meningkat. Hal ini mengindikasikan semakin dekatnya capaian kesetaraan gender di Indonesia (Rachmina, 2009). Namun demikian, persentase kekerasan terhadap perempuan juga cenderung terus meningkat setiap tahun. Penelitian terdahulu menyatakan bahwa kekerasan terhadap perempuan (istri) muncul sebagai salah satu bentuk manifestasi ketidaksetaraan gender (Nainggolan, 2012). Sejatinya, mengakhiri kekerasan terhadap perempuan dan anak merupakan suatu keharusan dan menjadi target yang harus dicapai pada tahun 2030 (KPPPA, 2017). Selaras dengan Program Nawacita (RPJMN 2015-2019), pemerintah terus berupaya memberikan perlindungan bagi perempuan dan anak dari tindak kekerasan melalui Program Three Ends atau 3 (tiga) akhiri, yakni: Akhiri Kekerasan Terhadap Perempuan dan Anak, Akhiri Perdagangan Manusia, dan Akhiri Ketidakadilan Akses Ekonomi untuk Perempuan.

Gambar 1. Perkembangan Capaian IDG dan Perkembangan Jumlah Kekerasan Terhadap Perempuan di Indonesia, 2010-2017

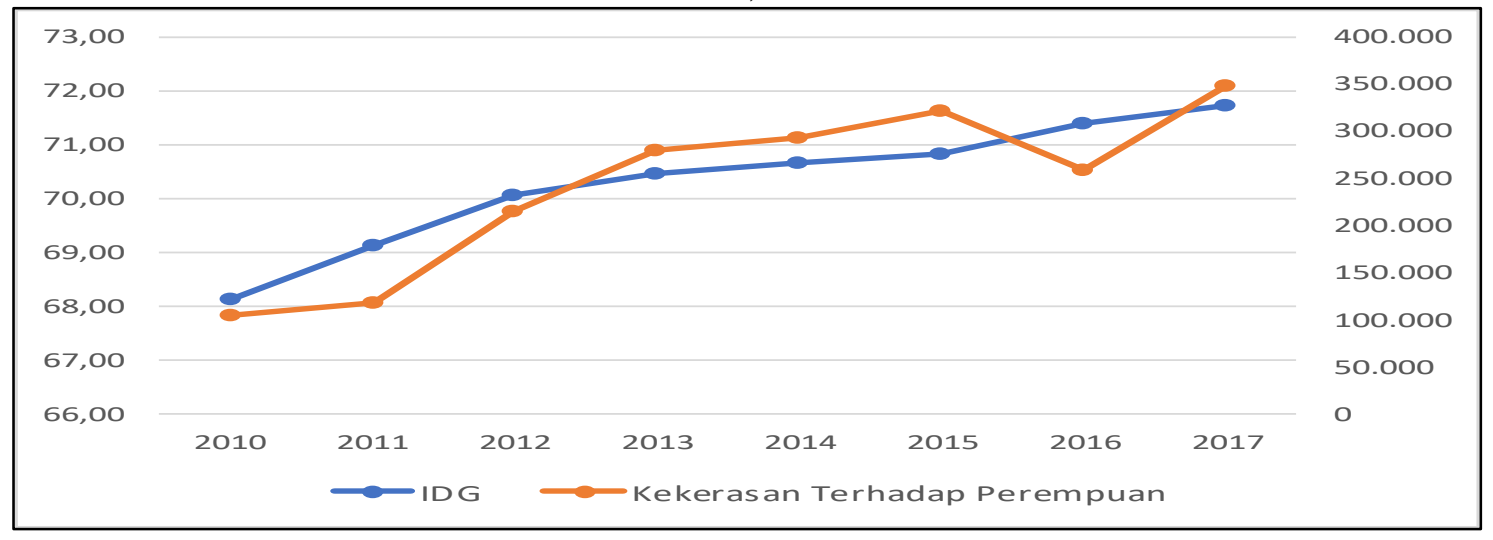

Sumber: BPS dan Komnas Perempuan (data diolah)

Komisi Nasional (Komnas) Perempuan mencatat terdapat 348.446 kasus kekerasan terhadap perempuan di tahun 2017. Sebanyak 335.062 kasus atau sekitar 96 persen berasal dari data Badan Peradilan Agama (Badilag) dan 13.384 kasus atau sekitar 3 persen berasal dari data 237 lembaga mitra pegada layanan. Jumlah kekerasan di tahun 2017 meningkat sekitar 25 persen dibandingkan tahun 2016 yang sebanyak 259.150 kasus. Meski, peningkatan jumlah kekerasan tersebut tidak serta merta menunjukkan pertambahan kasus kekerasan 
(BAPPENAS, 2013). Komnas Perempuan menyimpulkan bahwa hal ini dapat pula terjadi disebabkan oleh semakin banyaknya korban yang berani melapor. Kondisi serupa ditunjukkan dari hasil Survei Pengalaman Hidup Perempuan Nasional (SPHPN) 2016 oleh Badan Pusat Statistik (BPS) dan Kementerian Pemberdayaan Perempuan dan Perlindungan Anak (KPPPA), dimana satu dari tiga perempuan usia produktif (15-64 tahun) mengalami kekerasan fisik dan/atau seksual. Dari jumlah tersebut, perempuan tidak bekerja lebih banyak mengalami kekerasan dibandingkan perempuan bekerja. Dari sekitar 33,4 persen perempuan yang mengalami kekerasan, 24,3 persen diantaranya pernah mengalami kekerasan fisik dan seksual oleh pasangan maupun selain pasangan (KPPPA, 2017). Memburuknya tingkat kekerasan terhadap perempuan berimplikasi pada peningkatan kasus perceraian (Mayasari, 2013; Turangan, 2010). Bahkan, kekerasan dalam Rumah Tangga (KDRT) menjadi salah satu dari empat penyebab terbesar terjadinya perceraian (Komnas Perempuan, 2018).

$\begin{array}{ccr}\text { Oleh } & \text { karenanya, perlu } & \text { kiranya } \\ \text { dilakukan } & \text { penelitian } & \text { untuk } \\ \text { menggambarkan } & \text { karakteristik } & \text { kondisi }\end{array}$
pemberdayaan gender, kekerasan terhadap perempuan, dan perceraian sebagai dampak dari kekerasan sebagai upaya peningkatan kesejahteraan dan kesehatan perempuan, serta menjaga ketahanan keluarga.

\section{METODOLOGI}

Metode penelitian yang digunakan dalam tulisan ini adalah analisis deskriptif, yakni dengan mengkaji atau menganalisis data sekunder pada hasil Survei Sosial Demografi dan Kesehatan Indonesia (SDKI) 2017 dan Catatan Kekerasan terhadap Perempuan (CATAHU) Tahun 2018. Selain itu, dilakukan pula analisis komparatif, yakni dengan melakukan perbandingan antara hasil analisis yang diperoleh dengan teori yang ada melalui studi literatur (Sugiyono, 2007). SDKI 2017 dilaksanakan bersama oleh Badan Pusat Statistik (BPS), Badan Kependudukan dan Keluarga Berencana Nasional (BKKBN), dan Kementerian Kesehatan. Data pada CATAHU Komnas Perempuan tahun 2018 bersumber dari Badilag maupun kuesioner Komnas Perempuan yang diterima dari lembaga mitra yang mencakup Pengadilan Negeri (PN), Unit Pelayanan Perempuan dan Anak di Kepolisian (UPPA), Rumah Perlindungan/Trauma Center (Kementerian Sosial), Rumah Sakit (RS), Pusat Layanan Terpadu (PLT), Dinas Pemberdayaan Perempuan Perlindungan Anak dan Keluarga Berencana (DP3AKB), Organisasi Masyarakat Sipil (OMS)/Lembaga Swadaya Masyarakat (LSM), dan Women Crisis Center (WCC).

\section{KAJIAN PUSTAKA}

Pemberdayaan perempuan merupakan proses dimana perempuan dapat membuat pilihan hidup strategis dengan kemampuan yang dimiliki (Kabeer, 1999). Pemberdayaan perempuan mempunyai arti penting utamanya dalam aspek demografi dan kesehatan, seperti perencanaan keluarga berencana dan perawatan kesehatan ibu (BKKBN et al., 2018; Probosiwi, 2015). Pemberdayaan perempuan berdampak penting terhadap aspek kesehatan $(\mathrm{KB}$, perawatan kesehatan ibu dan anak) serta kemampuan terbebas dari kekerasan. Terdapat dua indikator pemberdayaan perempuan yang diukur dalam SDKI 2017. Indeks yang pertama menunjukkan jumlah keputusan dimana perempuan ikut berpartisipasi, baik sendiri maupun bersama pasangan atau suami. Keputusan rumah tangga yang dimaksud mencakup tiga aspek, yaitu perawatan kesehatan responden, pembelian kebutuhan utama rumah tangga, dan kunjungan ke keluarga atau kerabat responden. Indeks kedua adalah jumlah alasan dimana seorang perempuan berpendapat bahwa suami dibenarkan untuk melakukan 
pemukulan terhadap istri. Terkait dengan pengukuran ini, responden ditanyakan apakah setuju jika suami dibenarkan memukul istrinya bila terjadi 5 keadaan, yaitu istri menghanguskan masakan, membantah suami, pergi tanpa pamit, menelantarkan anak, dan menolak hubungan seksual. Kedua indeks tersebut mencerminkan status perempuan dalam rumah tangga dan masyarakat.

\section{HASIL DAN PEMBAHASAN}

Hasil SDKI 2017 menunjukkan bahwa secara nasional, sekitar 4,1 persen perempuan di Indonesia tidak berpartisipasi dalam membuat satu pun keputusan terkait perawatan kesehatan perempuan, pengeluaran besar dalam rumah tangga, maupun kunjungan ke keluarga/kerabat.

Persentase ketidaksertaan perempuan terhadap ketiga keputusan tersebut terbesar ada di Provinsi Gorontalo (10\%) dan terendah berada di Provinsi Sumatera Barat dan Sulawesi Utara $(0,7 \%)$. Secara rata-rata nasional, baru sekitar 68, 2 persen perempuan kawin umur 15-49 tahun yang biasanya ikut berpartisipasi dalam pengambilan keputusan untuk ketiga keputusan tersebut. Dari ketiga macam jenis keputusan yang ada, partisipasi perempuan dalam pengambilan keputusan terkecil adalah terkait pada pembelian kebutuhan utama rumah tangga.

Gambar 2. Persentase Partisipasi Perempuan Kawin (15-49 Tahun) di Indonesia dalam Pengambilan Keputusan, 2017

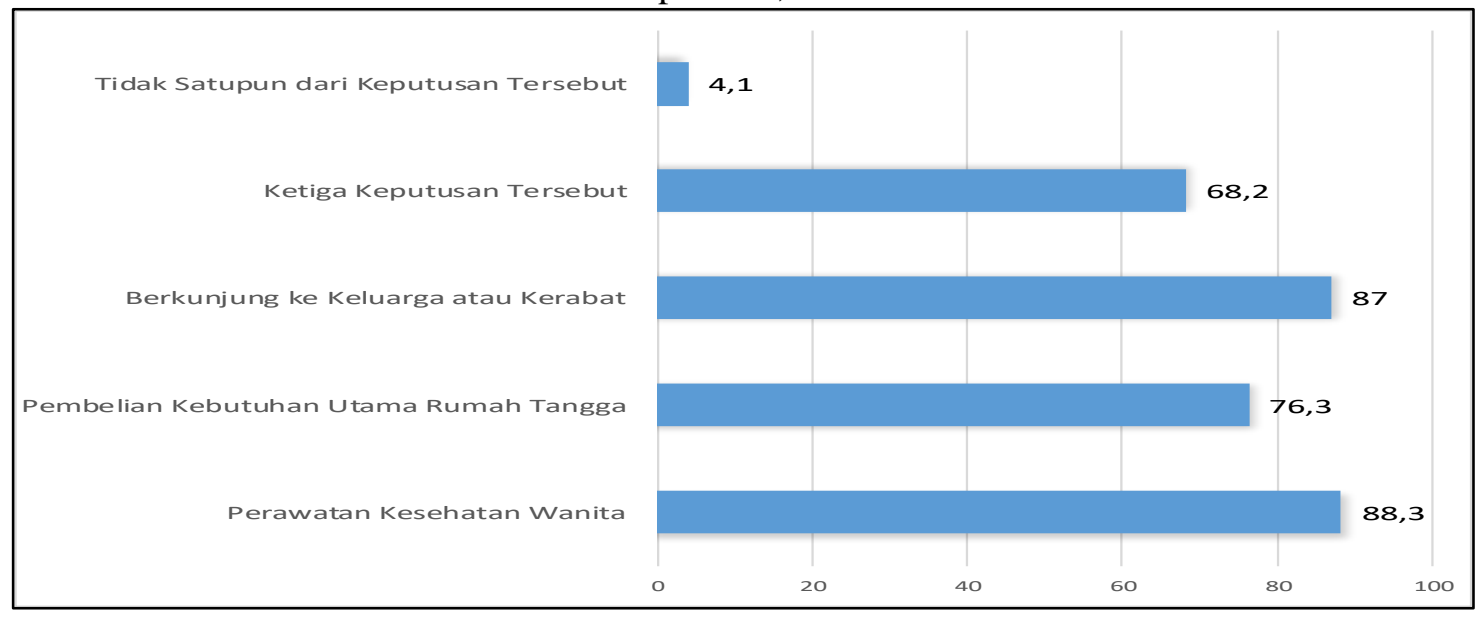

Sumber: BKKBN, et al., 2018 (data diolah)

Terkait dengan persepsi perempuan kawin (usia 15-49 tahun) terhadap alasan pembenaran pemukulan suami terhadap istri, sekitar 32 persen percaya bahwa suami dibenarkan memukuli istrinya dalam setidaknya 1 sampai 5 keadaan tertentu. Jumlah ini bahkan lebih besar dibandingkan responden laki-laki yang hanya sekitar 17 persen. Namun, patut pula dicermati bahwa terjadi penurunan dari responden perempuan, yakni dari 35 persen di tahun 2012. Sedangkan, responden laki-laki tetap 17 persen. Penurunan ini diduga terkait dengan peningkatan pendidikan, persentase perempuan, dan kuantil kekayaan (BKKBN et al., 2018).

Persentase perempuan (istri) umur 15-49 tahun yang menyetujui paling tidak satu dari 5 alasan tindakan suami melakukan pemukulan terhadap istri tertinggi berada di Provinsi Sulawesi Tenggara dan terendah berada di Provinsi Bali. Sedangkan, dilihat dari sudut pandang pria (suami), persentase setuju terbesar ditunjukkan di Provinsi Gorontalo dan terendah di Provinsi DI Yogyakarta. Diduga bahwa aspek budaya patriarki (Muhajarah, 2016) dan tingkat pendidikan (Sitorus, 2013) menjadi salah satu penyebabnya 
Gambar 3. Persentase Responden (Perempuan dan Laki-laki) yang Menyatakan Setuju atas Tindakan Pemukulan Suami terhadap Istri Menurut Provinsi di Indonesia, 2017

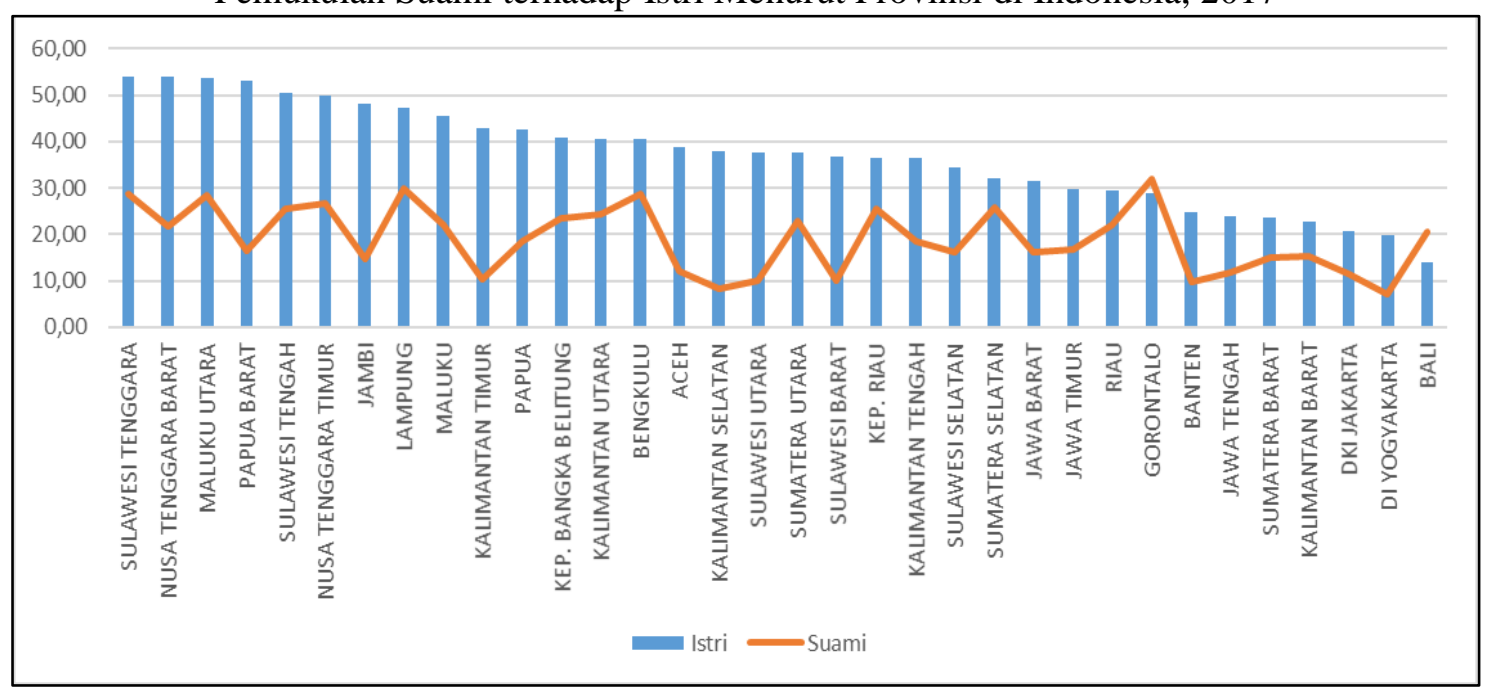

Sumber: BKKBN et al., 2018 (data diolah)

Indikator perempuan ditunjukkan pula dengan indikator kontrol atas pendapatan perempuan. Tanggung jawab perempuan pada tiga pekerjaan menyangkut fungsi produktif, reproduksi, dan sosial di komunitas menyebabkan secara ekonomi penghasilan laki-laki lebih tinggi dibandingkan perempuan (Noerdin, dkk., 2006). Berdasar pilihan keputusan terutama dilakukan oleh istri, persentase terbesar ditunjukkan di Provinsi Banten dan terendah di Provinsi Riau. Sedangkan keputusan yang utamanya dilakukan oleh suami, tertinggi berada di Provinsi Gorontalo dan terendah berada di Provinsi Banten. Selain itu, terdapat pula unsur yang menunjukkan kesetaraan dalam pengambilan keputusan, yakni istri bersama suami. Untuk kontrol atas penggunaan pendapatan yang dilakukan bersama antara istri dan suami, persentase terbesar berada di Provinsi Riau dan terendah di Provinsi Banten.

Perceraian merupakan salah satu dampak atau bentuk kekerasan terhadap perempuan. Baik kekerasan bersifat psikis, fisik, maupun ekonomis. Kekerasan yang dilakukan suami seringkali menjadi penyebab terjadinya perceraian (Matondang, 2014). Data yang dihimpun oleh Komnas Perempuan menunjukkan adanya kecenderungan peningkatan jumlah perceraian. Data yang digunakan bersumber dari data Pengadilan Agama (PA). Pengadilan Agama (PA) mengkategorikan penyebab perceraian dalam 14 jenis, yaitu zina, mabuk, madat, judi, meninggalkan salah satu pihak, dihukum penjara, poligami, kekerasan dalam rumah tangga (KDRT), cacat badan, perselisihan dan pertengkaran terus menerus, kawin paksa, murtad, ekonomi, dan lain-lain.

Empat penyebab terbesar terjadinya perceraian di Indonesia ditunjukkan pada Gambar 4. Secara persentase, perselisihan dan pertengkaran terus menerus merupakan penyebab terbanyak (sekitar 41\%). Faktor ketidakharmonisan menyebabkan terjadinya ketidakcocokan, perselisihan, kecemburuan, gangguan dari pihak luar yang berujung pada perceraian (Amalia et al., 2017). Ada dugaan bahwa alasan sesungguhnya penyebab perceraian mencakup pula KDRT. Namun, penggugat (istri) cenderung sungkan mengungkap fenomena ini karena faktor budaya patriarki (Busriyanti, 2012, Rahmawati, 2016), tekanan sosial, tidak ingin disalahkan, dan sulitnya pembuktian (Komnas Perempuan, 2018). 
Gambar 4. Persentase Empat Penyebab Terbesar Perceraian di Indonesia, 2017

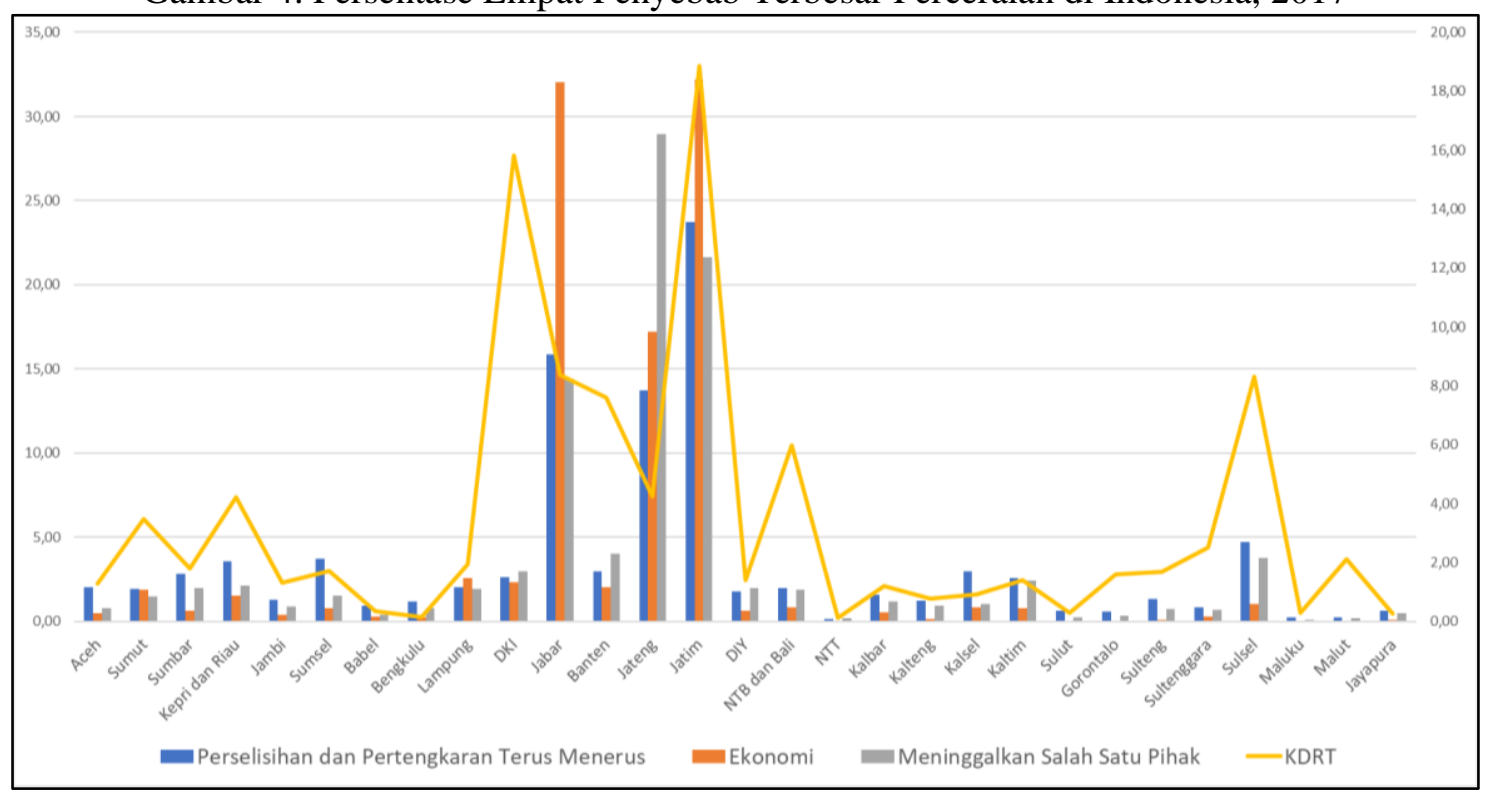

Sumber: Badilag (data diolah)

Berdasarkan empat penyebab terbesar perceraian, urutan persentase total perceraian tertinggi tahun 2017 tercatat di Provinsi Jawa Timur dan terendah di Provinsi Nusa Tenggara Timur. Di Provinsi Jawa Timur terlihat bahwa persentase dari masing-masing penyebab terjadinya perceraian merupakan yang terbesar di antara provinsi lainnya. Terlihat pula bahwa persentase perceraian di Pulau Jawa masih mendominasi persentase total perceraian. Hal ini didukung dari besarnya persentase total perceraian di Jawa Barat, Jawa Tengah, Banten, dan DKI Jakarta. Sedangkan, wilayah timur Indonesia cenderung memiliki total persentase perceraian yang terendah. Selain NTT, rendahnya perceraian terlihat pada data di Provinsi Maluku Utara dan Provinsi Maluku.

Selain itu, analisis terhadap data Komnas Perempuan menunjukkan bahwa karakteristik korban kekerasan terhadap perempuan yang diidentifikasi berdasarkan usia, pendidikan, dan profesi menunjukkan bahwa korban di ranah personal (KDRT) utamanya adalah perempuan yang berada dalam usia produktif, baik dari segi sosial maupun biologis. Sedangkan, dilihat dari sisi karakteristik pelaku, utamanya berpendidikan terakhir SLTA dan dalam usia produktif di atas 25 tahun. Hal ini mengindikasikan adanya ancaman terkait fungsi dan peran dalam proses reproduksi untuk menghasilkan generasi mendatang.

Salah satu dari keempat penyebab terbesar perceraian adalah KDRT. Berdasarkan laporan layanan pengaduan yang dicatat dalam CATAHU, terlihat bahwa persentase kekerasan terhadap perempuan terbanyak berada di Provinsi DKI Jakarta. Diikuti dengan provinsiprovinsi lain di Pulau Jawa. Sedangkan, yang terendah berada di Provinsi Sulawesi Barat. Dalam hal ini, kekerasan terhadap perempuan (KTP) di Provinsi Papua cenderung tembus pandang dalam CATAHU, tidak terdokumentasi sehingga tidak ada peta penanganan (Komnas Perempuan, 2018). Hasil ini dapat pula menjadi gambaran bahwa aspek demografi ikut berpengaruh terhadap keputusan dan keberanian perempuan untuk melaporkan tindak kekerasan yang dialami selain dari lebih baiknya pengolahan data yang dilakukan oleh lembaga layanan pengaduan. 
Gambar 5. Persentase Kekerasan Terhadap Perempuan di Indonesia Berdasar Laporan Layanan Pengaduan, 2017

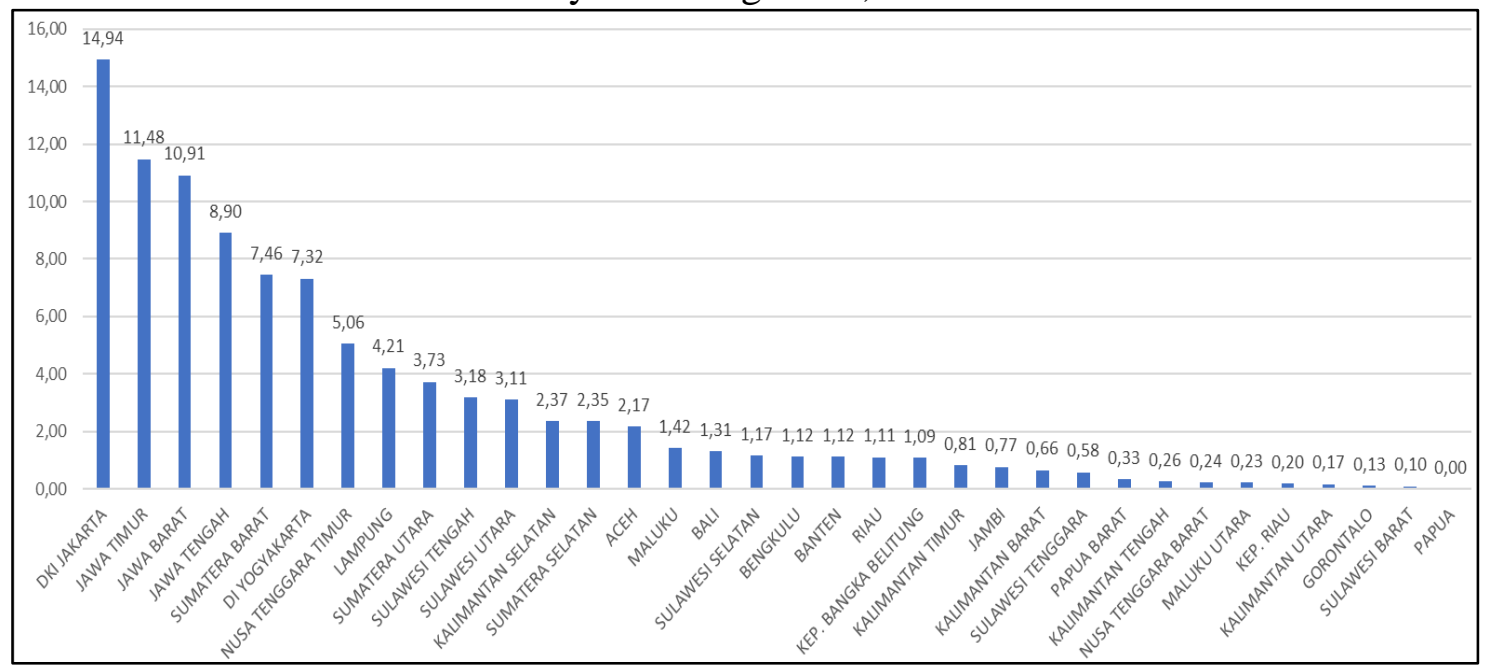

Sumber: Layanan Pengaduan Mitra Komnas Perempuan (data diolah) terhadap indikator pemberdayaan perempuan dan kekerasan terhadap perempuan yang berdampak pada perceraian memperlihatkan bahwa partisipasi perempuan dalam pengambilan keputusan di rumah tangga dan kontrol perempuan terhadap pendapatan yang dihasilkan memiliki keterkaitan dengan persentase perempuan yang setuju maupun tidak setuju dengan semua alasan yang membenarkan pemukulan suami terhadap perempuan (istri). Hasil ini sejalan dengan penelitian yang dilakukan oleh Diana (2016).

Perbandingan antara kedua indikator pemberdayaan gender tersebut selaras pula dengan pola distribusi persentase kekerasan terhadap perempuan maupun persentase perceraian berdasarkan penyebab terbesar terjadinya perceraian. Secara umum, semakin tinggi partisipasi dan kontrol yang dimiliki perempuan, maka perempuan semakin tidak setuju dengan semua alasan untuk membenarkan pemukulan suami terhadap istri. Hal ini menunjukkan bahwa ke depan sikap tersebut mampu mengurangi kekerasan dalam rumah tangga (KDRT) sebagai penyebab perceraian. Contoh yang bisa diambil adalah Provinsi Gorontalo. Kontrol terhadap pendapatan istri utamanya dilakukan oleh suami dan persentase setuju atas alasan pemukulan terhadap istri dari sudut pandang suami juga tertinggi di antara seluruh provinsi yang ada. Dihubungkan dengan penyebab utama perceraian, alasan KDRT menjadi alasan terbesar penyebab perceraian di Provinsi Gorontalo. Sistem sosial budaya yang masih cenderung patrilineal berdampak pada persentase pengambilan keputusan yang dilakukan oleh perempuan (Sahi, 2012).

\section{KESIMPULAN}

Peningkatan capaian IDG sepanjang tahun 2010-2017 sejalan dengan peningkatan jumlah kekerasan terhadap perempuan. Meski peningkatan jumlah kekerasan terhadap perempuan tidak serta merta menunjukkan penambahan kejadian kekerasan. Melainkan dapat pula diartikan adanya peningkatan kesadaran dan keberanian perempuan untuk melaporkan tindak kekerasan. Hal ini menjadi sinyal positif akan adanya peningkatan upaya pemberdayaan perempuan di Indonesia. Selain IDG, indikator pemberdayaan perempuan juga ditunjukkan dalam kontrol perempuan atas penghasilan yang dimiliki, partisipasi perempuan dalam pengambilan keputusan di rumah tangga, dan sikap perempuan terhadap pemukulan suami terhadap isteri. Hasil penelitian 
menunjukkan adanya kecenderungan bahwa semakin banyak perempuan berpartisipasi dalam pengambilan keputusan di rumah tangga, maka semakin banyak perempuan yang tidak setuju dengan semua alasan untuk membenarkan pemukulan suami terhadap istri. Namun, masih perlu dilakukan penelitian lebih mendalam terkait dengan hubungan di antara indikator-indikator pemberdayaan perempuan, kekerasan dalam rumah tangga, dan jumlah perceraian dengan memperhatikan perbedaan karakteristik sosial budaya di masing-masing provinsi sehingga gambaran yang diperoleh dapat lebih akurat. Pada akhirnya, hal ini akan mampu mengurangi jumlah kekerasan dalam rumah tangga. Upaya penguatan peraturan perundang-undangan berbasis gender juga harus terus ditingkatkan sebagai upaya perwujudan kesejahteraan perempuan yang akan berdampak pada ketahanan keluarga.

\section{DAFTAR PUSTAKA}

Amalia, R.M., Akbar, M.YA., Syariful, S., (2017). Ketahanan keluarga dan kontribusinya bagi penanggulangan faktor terjadinya perceraian. Jurnal Al-Azhar Indonesia Seri Humaniora. Vol 4 No 2.

BAPPENAS. (2013). Pembangunan kesetaraan gender background study RPJMN III (2015-2019). Jakarta: Kementerian Perencanaan Pembangunan Nasional/Badan Perencanaan Pembangunan Nasional (BAPPENAS)

BKKBN, BPS, Kemenkes. (2018). Survei demografi dan kesehatan indonesia 2017. Jakarta: BKKBN.

BPS. (2017). Kajian indikator lintas sektor: indikator tujuan pembangunan berkelanjutan indonesia. Jakarta: Badan Pusat Statistik.
Busriyanti. (2012). Islam dan kekerasan terhadap perempuan. Religio: Jurnal Studi Agama-agama. Vol 2 No 2.

Diana, L.A. (2016). Measuring women's empowerment: lesson to better understand domestic violence. PSE Working Papers. $\mathrm{n}^{0} \quad 2016-04$ $<$ halshs-01294565>.

Kabeer, N. (1999). Resources, agency, achievements: reflections on the measurement of women's empowerment in Development a change. Vol 30 pp 435-464. Institute of Social Studies: Blackwell Publisher Ltd. Diakses dari https://www.utsc.utoronto.ca/ kmacd /IDSC10/Readings/research\%20desi gn/empowerment.pdf.

KPPPA. (2017). Statistik gender tematik Mengakhiri kekerasan terhadap perempuan dan anak di indonesia. Jakarta: Kementerian Pemberdayaan Perempuan dan Perlindungan Anak.

Komnas Perempuan. (2018). Catatan kekerasan terhadap perempuan tahun 2018 "Tergerusnya ruang aman perempuan dalam pusaran politik populisme”. Jakarta: Komisi Nasional Perempuan.

Matondang, A. (2014). Faktor-faktor yang mengakibatkan perceraian dalam perkawinan. Jurnal Ilmu Pemerintahan dan Sosial Politik, 2 (2): 141-150.

Mayasari, D.E. (2013). Tinjauan yuridis adanya kekerasan dalam rumah tangga sebagai alasan untuk melakukan perceraian. Jurnal Mimbar Hukum. Vol 25 No 3.

Muhajarah, K. (2016). Kekerasan terhadap perempuan dalam rumah tangga: Perspektif sosio-budaya, hukum, dan agama. Jurnal Studi Gender. Vol 11 No 2. 
Nainggolan, T., (2017). Kekerasan terhadap istri dalam perspektif gender. Sosio Konsepsia: Jurnal Penelitian dan Pengembangan Kesejahteraan Sosial. Vol 14 (3): 204-215.

DOI 10.33007/ska.v14i3.709.

Noerdin, E., et al. (2006). Potret kemiskinan perempuan. Jakarta: Women Research Instutite.

Probosiwi, R. (2015). Perempuan dan perannya dalam pembangunan kesejahteraan sosial. Jurnal Kajian Ilmu Administrasi Negara. Vol 3 No 1.

Rachmina, D. (2009). Fenomena kesetaraan gender dalam kredit. Jurnal Agribisnis dan Ekonomi Pertanian. Vol 3 No 1.

Rahmawati, N. N. (2016). Perempuan bali dalam pergulatan gender (kajian budaya, tradisi, dan agama hindu). Jurnal Studi Kultural. Vol 1 No 1: 58-64.

Sahi, NA. (2012). Studi partisipasi politik perempuan kabupaten gorontalo.
Jurnal Ilmu Administrasi (JIA). ejournal.unsrat.ac.id.

Santi, S. (2007). Perempuan dan kemiskinan: pembangunan, kebijakan, dan feminisasi kemiskinan. Forum Ilmiah Indonusa. Vol 4 No 1.

Sitorus, AVY., (2013). Dampak ketimpangan gender terhadap pertumbuhan ekonomi di Indonesia. Masters thesis, Institut Pertanian Bogor.

Sugiyono. (2007). Metode penelitian kuantitatif, kualitatif, dan $R \& I$. Bandung: Alfabeta.

Turangan, D.D. (2010). Kekerasan dalam rumah tangga sebagai alasan perceraian. Karya Ilmiah Universitas Sam Ratulangi Manado.

UN. (2015). Gender Equality: Why It Matters. diperoleh 21 November 2018, dari http://www.un.org/sustainabledevelo pment/gender-equality. 